\title{
EFFECT OF ENRICHED COPEPODS ON THE GROWTH, SURVIVAL AND COLOURATION OF ANGELFISH (Pterophyllum scalare)
}

\author{
NIZALMIE AZANI ${ }^{1}$ AND NADIAH W RASDI ${ }^{2,3^{*}}$
}

\begin{abstract}
${ }^{l}$ Institute of Tropical Aquaculture and Fisheries, Universiti Malaysia Terengganu, 21300 Kuala Nerus, Terengganu, Malaysia. ${ }^{2}$ Faculty of Fisheries and Food Sciences, University Malaysia Terengganu, 21030 Kuala Nerus, Terengganu, Malaysia ${ }^{3}$ Institute of Tropical Biodiversity and Sustainable Development
\end{abstract}

*Corresponding author: nadiah.rasdi@umt.edu.my

http://doi.org/10.46754/umtjur.2021.04.003

\begin{abstract}
Cyclopoid copepod has a potential as live feed that can provide ornamental fish larvae with energy and essential nutrients, and promote their growth and survival, as well as affect their colouration. However, the nutrition, growth and nutritional requirements of this species are poorly understood. This research focuses on comparing the efficacy of enrichment types on copepods towards the growth rate, survival rate and colouration of Pterophyllum scalare larvae. The enrichment of copepods consists of four enrichment procedures (rice bran, palm kernel cake (PKC), Chlorella and yeast). This study was carried out over 50 days and the growth rate, survival rate and colouration (growth rate, survival rate, SGR and colouration) were used to evaluate the responses of $P$. scalare larvae towards different enrichment methods. Specific growth rates $(8.0161 \pm 1.4928$ $\% ; P=0.775)$ and survival rates $(66.667 \pm 5.337 \% ; P=0.815)$ of fish larvae were found to not be significantly different $(P=0.775, P=0.815 ; P>0.05)$. However, the colouration of the fish larvae was affected by the types of enrichment used $(P<0.05)$. The growth and survival rates of $P$. scalare larvae were highest when fed with copepod enriched with rice bran and PKC. This enrichment type is the regulating factor for the growth rate, survival rate and colouration of $P$. scalare. The present study indicates that the organic fertilisers used, such as rice bran and $\mathrm{PKC}$, have the potential for the aquaculture industry as an important enrichment medium for the growth and survival of fish larvae. Our results showed that both enrichment methods are applicable for the substitution of yeast and these findings will therefore provide better enrichment options in the larval rearing of the ornamental fish $P$. scalare. This study will allow the potential use of other live feed enrichment formulas to ensure that fish larval development is maintained in hatcheries.
\end{abstract}

Keywords: Copepod, Angelfish, proximate, larvae, coloration.

\section{Introduction}

Marine and freshwater species of zooplankton are generally used to provide fish larvae with nutrients. They provide energy and are a main source of nutrients for the production and growth of larvae. The significance of copepods in aquaculture, especially in the larval rearing of most marine fish, has been recognised. Most larvae mainly feed on copepods (Rasdi \& Qin, 2016). The dry-weight protein concentration of copopods is higher than rotifers, but it cannot easily be enriched (Hamre et al., 2013). Maximum survival and growth rates were recorded in copepod-fed fish larvae (Santhanam, 2012). Copepods are sometimes used as biodiversity indicators. They are therefore widely considered superior to rotifers and Artemia for fish larvae cultures (Zeng et al., 2018). Copepods feed on small algae and serve as a nutrient source for millions of other aquatic life. In recent years, fish nutrition has improved spectacularly with the development of new and balanced commercial diets that offer ideal fish health maintenance and growth rate (Craig et al., 2017). A good appreciation of all these factors is needed for the successful production of fish.

Studies of fish larvae have shown that copepod nauplii are the essential food of various fish species (Marcus, 2005). Nowadays, enrichment techniques are applied to a wide 
variety of macro and micronutrients and include techniques to minimise or alter the overall nutritional value of fish. Copepods are a splendid candidate in terms of nutritional composition as they possess higher levels of HUFA, and they contain an amended balance between triglyceride and phospholipid lipid classes (Dhont et al., 2013).

Nowadays, the angelfish (Pterophylum scalare) are popular among ornamental fish pet keepers due to their unique shape and interesting personalities (Uyeno et al., 2009). Unfortunately, aquaculturists have not formulated an optimal diet to enhance the colouration of the fish. The angelfish ( $P$. scalare) is a disk-shaped cichlid. In the natural habitat, they are found to have black bars on a silver-coloured body (Feltwell, 2016). Angelfish are one of the most crucial cichlid species. Angelfish tend to breed in pairs. The compromising of the fish larvae is also hard to determine and meet in terms of nutritional requirements, and may inhibit growth or a proper development (Hamre et al., 2013). There is also very little information on the nutritional needs and growth of the species, as well as factors that are critical for the release of the species on the aquaculture sector. (Koca, 2009; Espitia et al., 2017). Furthermore, the industrial development of ornamental freshwater fish cultivation was limited by insufficient live feed for different stages of production. (Lim et al., 2003)

Live feed is the most important resource for aquaculture in an aquatic environment. The majority of natural fish feed on phytoplanktonic and zooplanktonic species. Natural fish feed is typically not common in freshwater clear ponds but is abundant in ponds with greenish water. The green colour indicates the existence of phytoplankton, as well as other live feed, and thorough nutrition is among the most serious factors in fish larvae production. (Koven et al., 2001). Zooplanktons are a significant part of the larval diet in the natural food network, and it is widely accepted that copepods can fulfil the nutritional needs of fish larvae (Evjemo et al., 2003). Sustaining the copepod in the hatchery is quite difficult. Studies measuring the optimum conditions for the development of intensive zooplankton are lacking. Nutrition is recognised to be among the most critical barriers to the implementation of fish larvae (Koven et al., 2001).

The findings of this study can be useful to the industrial society, especially to the aquaculture industry. A current obstacle in observational studies is observing growth performance as malnutrition is one of the major determinants of larval growth and survival rate decline (Conceição et al., 2010). The nutritional criterion is often calculated as the highest growth provision and survival rate, which have important effects on the fortitude of the perceptible needs of fish diet feeding. (Hamre et al., 2013). So, we need to give the best starter feed to them. Hence, the priority of copepods in aquaculture has been recognised at various stages. Apart from that, it is shown that copepods play a key role in the food web ecosystem. Copepods also have been proven to be a nutritionally sufficient live feed for the rearing of the larvae of most species (Busch et al., 2011). In order to ensure the success of an aquaculture, it is important to understand the growth performance, survival rate and colouration of fish. A significant amount of zooplanktons rely on the intense larval culture of most marine fish (Onianwah, 2018).

Moreover, in terms of nutritional value, live feed is distinct from artificial feed. (Das et al., 2012). Copepods were also able to produce high yield of biomass and lipid productivity under normal and various nutrient-deprived conditions (Praveenkumar et al., 2012) Enrichment, such as rice bran, is high in vitamins, minerals, essential fatty acids, dietary fiber and other sterols, which is important for ornamental fish larvae, through zooplankton enrichment (Gul et al., 2015).

Colouration is also one of the most important parts in the ornamental industry. Colouration can be obtained through carotenoid. Carotenoid is a lipid-soluble pigment, and it is synthesised by photosynthetic organisms. It must be obtained through diet. Carotenoid cannot be synthesised endogenously (Kouba et al., 2013). These pigments have attracted increasing attention. 
In addition, it has a number of positive impacts on animal physiology, such as the precursor vitamin $\mathrm{A}$, and is thought to have a function in sensing (Moren et al., 2002), in immunisation (Amar et al., 2001), light defense (Palace et al., 2006) or as antioxidants (McGraw et al., 2005). Carotenoid-based ornamentation was suggested as signifiers for the ability to obtain and assimilate carotenoids in their diet.

The aim of this study is to improve the production of commercial ornamental freshwater fish and evaluate the effects of enriched copepods on the growth performance, survival rate and colouration of angelfish. This study also aims to calculate the efficiency of enrichment types on copepods and the growth rate, survival rate and colouration of $P$. scalare larvae. So, we need to keep angelfish feed with good nutrition and aim to keep fish in good health. Otherwise, the ornamental fish business depends upon colour.

\section{Material and Method}

\section{Sampling and Culturing}

Copepods were sampled from Setiu, Terengganu, Malaysia. The copepods were cultivated and maintained at the Universiti Malaysia Terengganu hatchery. The temperature and salinity were monitored and maintained within an optimum range. The optimum temperatures for habitats are between $26^{\circ} \mathrm{C}$ and $27^{\circ} \mathrm{C}$, and the average salinity is between 24 and $26 \mathrm{ppt}$ (Zaleha \& Busra, 2012). The copepods were first cultivated in a 1000L tank as a stock culture. Regular feeding and observation were provided. Apart from that, $30 \%$ of the water were modified once every two days to prevent pollution and toxicity by food.

\section{Experimental Design and Setup}

Freshwater was filtered through GFC membrane filters after being passed through a UV treatment before being used. Beakers with capacities of 0.5 $\mathrm{L}$ and $1 \mathrm{~L}$ were used as the culture vessels. The cultures were maintained at a salinity of between
22 to $26 \mathrm{ppt}$ and temperatures of between $26{ }^{\circ} \mathrm{C}$ to $27^{\circ} \mathrm{C}$. The cultures were fed daily with yeast, rice bran, Chlorella sp. and Palm kernel cake (PKC) at a density of $1 \times 10^{6}$ cell $\mathrm{ml}^{-1}$ (Zaleha \& Busra 2012). No aeration was provided for the $0.5 \mathrm{~L}$ and $1 \mathrm{~L}$ stock cultures.

Angelfish were bred and this experiment was performed with angelfish larvae. Before the beginning of the experiment, the angelfish larvae were randomly divided into 12 groups; 4 treatments with triplicate (Berchielli-Morais et $a l ., 2016)$. Each treatment was given different enrichments, which are yeast (as control), rice bran, Chlorella sp. and PKC. The initial weight of the fish was weighed, and the body weight gain of the fish was measured individually.

\section{Enrichment}

The copepods need to be enriched. The copepods from the stock were transferred to a $10 \mathrm{~L}$ aquarium and enriched with four different types of diets for 24 hours (Brown, 2002). The copepods were enriched as we wanted the copepod to have a better reproduction and growth rates. The copepods are then used as a live feed to increase the survival rate of the fish larvae. Live feed is important in the early stages of fish larvae as they are biologically incapable of processing inert diet through their nascent digestive system. The enrichment of copepods provided better nutritional contents for fish or fish larvae. The concentration for the enrichment was $1 \times 10^{6}$ for algae, which is equivalent to $500 \mathrm{mg} \mathrm{L}^{-1}$ of dry enrichment (Zaleha \& Busra, 2012).

\section{Angelfish Larvae Rearing}

The angelfish larvae were cultured in an aquarium tank with aeration. A gentle filtration system was required. Other than that, all parameters, such as temperature, salinity, nitrite, nitrate, $\mathrm{pH}$, were observed to ensure a good condition. Fish were maintained under the following water parameters: temperature of 27.0 ${ }^{\circ} \mathrm{C}$ and $\mathrm{pH}$ of $8.4 \pm$ (Salas, 2009). The tank was washed regularly to eliminate detritus contents 
at the floor and a frequent water adjustment of at least $1-2 / 3$ of the volume of the tank was conducted on a weekly basis. The tank was mildly acidic, with an optimum $\mathrm{pH}$ of 6.7. The water temperature was approximately $26{ }^{\circ} \mathrm{C}$. The success of the hatchery development of fish fingerlings in the grow-out production system depends almost entirely on the availability of adequate live feed organisms to feed fish larvae until the juvenile stage (Das et al., 2012).

\section{Growth Rate and Survival Rate}

According to Berchielli-Morais (2016), the following formula was used to calculate the specific growth rate.

The weight gain of the body was calculated individually. The parameters of growth performance were obtained using the following equations:

$$
\operatorname{SGR}\left(\% \text { day }^{-1}\right)=[\ln (\mathrm{Fw})-\ln (\mathrm{Iw}) / \mathrm{d}] \mathrm{X} 100
$$

Where

$\mathrm{FW}=$ Final weight

$\mathrm{Iw}=$ Initial weight

$\mathrm{d}=$ number of days

$$
\text { Weight gain }(\mathrm{g})=\mathrm{Fw}-\mathrm{Iw}
$$

Where

$\mathrm{FW}_{\mathrm{W}}=$ Final mean weight

$\mathrm{Iw}=$ Initial mean weight

Survival rate (\%) of angelfish larvae fed on different diet;

Percent of survival $(\%)=($ Survival fish $/ \mathrm{n}) \mathrm{X} 100$

Where

Survival fish $=$ number of survival fish

$\mathrm{n}=$ total number fish stocked

\section{Colouration}

The fish were chosen randomly and anesthetised at lower temperatures for around 10 minutes to determine the colour of their skin. The evaluation was performed by reflectance spectroscopy with transformation into colour variables based on the values of tristimulus, $L^{*}, a^{*}, b^{*}$, lightness, redness and yellowness, respectively. (Trujillo et al., 1996). According to Sharma (2013), skin colour was measured at the centre of the body area of all fish. Measurements were recorded at the end of the feeding trial using a Chroma Meter (colorimeter). Recordings will be made according to the colour system mode of the International Commission on Illumination $(\mathrm{CIE}): \mathrm{L}^{*}=$ lightness, where dark $=0$, and white $=100 ; a^{*}=$ red, where positive values $=$ red, and negative values $=$ green; $b^{*}=$ yellow, where positive values $=$ yellow, and negative values $=$ blue. Hue $\left(\mathrm{H}_{\mathrm{o}} \mathrm{ab}\right)$ and chroma $\left(\mathrm{C}^{*}\right)$ were calculated using the following formulae: if $\mathrm{a}^{*}>0$ then $\mathrm{H}_{\mathrm{o}} \mathrm{ab}=\tan -1\left(\mathrm{~b}^{*} / \mathrm{a}^{*}\right)$, but if $\mathrm{a}^{*}<0$ then $\mathrm{H}_{\mathrm{o}} \mathrm{ab}$ $=180+\tan -1\left(b^{*} / a^{*}\right) ; \mathrm{Cab}^{*}=\left(a^{*} 2+b^{*} 2\right) 1 / 2$

\section{Proximate Analysis}

The weight of the samples was measured. The samples were packed in separate polyethene bags, labelled and stored in a freezer at $-20^{\circ} \mathrm{C}$ for further laboratory analyses. Protein, lipid, moisture, and ash were analysed at the Department of Fisheries laboratory of Universiti Malaysia Terengganu. The method protocol was not provided, but the method references provided were as follows: protein, lipid, moisture and ash (AOAC, (1962) (Woods \& Velentino, 2003). The method used were as follows:

The total protein content of the larvae was determined using the Micro-Kjeldhal process. (Pearson, 2000).

The protein percentage determined by multiplying the percentage of N2 (\%) with an empirical factor 6.25 .

Protein $(\%)=$ percentage of total amount of $\mathrm{N} 2$ $\times 6.25$.

The total lipid content of larvae was measured using the Bligh and Dyer method (2000). The percentage of lipid calculated by: 
Percentage of fat $(\%)=($ weight of the extract $/$ weight of the sample) $\times 100$.

The moisture concentration was determined using the hot air oven method used by Jain and Singh (2000). The percentage was calculated by:

Percentage $(\%)$ of moisture $=($ weight loss $/$ actual weight of the sample $) \times 100$

The ash content of the larvae was evaluated by the AOAC method (2000). The percentage of ash content was estimated by:

Ash (\%) = weight of ash/weigh of sample $\times$ 100 .

\section{Data Analysis}

Data was presented as a mean \pm standard deviation (SD). All data were obtained during the experiment and merged together to be evaluated using a one-way variance analysis (ANOVA). This is done to compare the growth, survival and colouration of the angelfish larvae (P. scalare). Differences at $\mathrm{P}<0.05$ are considered significant. Where the main treatment impact was significant, post-hoc comparison was performed using the Tukey test. In order to satisfy the assumptions of ANOVA, all of the data will be evaluated for normality, homogeneity and independence.

\section{Results}

\section{Specific Growth Rate (SGR)}

Table 1 shows the overall growth rate of the angelfish larvae and enrichment after test feeding for 50 days. The highest specific growth rate of the angelfish larvae occurred when the larvae were fed with rice bran $\left(8.93 \pm 0.33^{\mathrm{b}} \%\right)$, compared with other treatments for feeding $(P$ $<0.05$, Table 1). Angelfish larvae fed with yeast produced a lower growth rate $\left(7.81 \pm 0.16^{\mathrm{a}} \%\right)$ than those fed with PKC and Chlorella sp. (8.50 $\pm 0.29^{\mathrm{a}} \%$ and $8.34 \pm 0.47^{\mathrm{a}, \mathrm{b}} \%$ ). The specific growth rate of the angelfish larvae was based on the type of enrichment given $(P<0.05$; Table 1$)$.
Table 1: The specific growth rate (SGR) of angelfish P. scalare larvae fed with different enrichment.

All values are expressed in terms of mean \pm standard deviation $(n=4)$. The different small letters indicate significant differences between enrichment treatments $(P<0.05)$

\begin{tabular}{ll}
\hline Enrichment & Specific Growth Rate (\%) \\
\hline Rice bran & $8.93 \pm 0.33^{\mathrm{b}}$ \\
Palm kernel cake & $8.50 \pm 0.29^{\mathrm{b}}$ \\
Chlorella sp. & $8.34 \pm 0.47^{\mathrm{a}, \mathrm{b}}$ \\
Yeast (control) & $7.81 \pm 0.16^{\mathrm{a}}$ \\
\hline
\end{tabular}

\section{Survival Rate}

The survival of the angelfish larvae depended on the enrichment type $(P=0.01 ; P<0.05)$. Higher survival rate of Angelfish larvae resulted from Chlorella sp. (72.33 $\left.\pm 2.52^{\mathrm{b}} \%\right)$ and the survival rate of the angelfish larvae fed with rice bran, PKC and yeast were $\left(68.33 \pm 2.51^{\mathrm{a}, \mathrm{b}} \%\right),(66.33$ $\left.\pm 2.89^{\mathrm{a}, \mathrm{b}} \%\right)$ and $\left(61.00 \pm 3.61^{\mathrm{a}} \%\right)$, respectively.

Table 2: The survival rate of the angelfish $P$. scalare larvae fed with different enrichment. All values are expressed in terms of mean \pm standard deviation $(n=4)$. The different small letters indicate significant differences between treatment $(P<0.05)$

\begin{tabular}{ll}
\hline Enrichment & Survival Rate (\%) \\
\hline Rice bran & $68.33 \pm 2.51^{\mathrm{a}, \mathrm{b}}$ \\
PKC & $66.33 \pm 2.89^{\mathrm{a}, \mathrm{b}}$ \\
Chlorella & $72.33 \pm 2.52^{\mathrm{b}}$ \\
Yeast (control) & $61.00 \pm 3.61^{\mathrm{a}}$ \\
\hline
\end{tabular}

\section{Colouration}

The colouration reading of the Aangelfish larvae depended on the enrichment type $(P=0.01$; $P<0.05)$. Higher chroma, lightness and Hue reading of the angelfish larvae was the result of rice bran $(9.17 \pm 0.83 * \mathrm{C}, 69.06 \pm 2.65 * \mathrm{~L}$ and $113.25 \pm 1.27 \mathrm{H}^{0}{ }_{\mathrm{ab}}$ ) and the colouration reading of the angelfish larvae fed with PKC, Chlorella $\mathrm{sp}$. and yeast were $(8.23 \pm 0.63 * \mathrm{C}$, $\left.62.84 \pm 2.64 * \mathrm{~L}, 111.32 \pm 0.93 \mathrm{H}^{0}{ }_{\mathrm{ab}}\right),(7.33 \pm$ $\left.1.24 * \mathrm{C}, 55.65 \pm 3.70 * \mathrm{~L}, 110.80 \pm 1.03 \mathrm{H}_{\mathrm{ab}}^{0}\right)$ and $(5.27 \pm 0.77 * \mathrm{C}, 55.39 \pm 4.54 * \mathrm{~L}, 105.46 \pm$ $1.07 \mathrm{H}^{0}{ }_{\mathrm{ab}}$ ), respectively. The colouration reading of Angelfish larvae depended on the enrichment type provided $(P<0.05$; Table 3$)$. 
Table 3: The colour reading of the angelfish larvae fed with different enrichment and colour assessments. All value are expressed in terms of mean \pm standard deviation $(n=4)$. The letters indicate significant differences between different colour assessments $(P<0.05)$

\begin{tabular}{llc}
\hline Color assessment & Enrichment & Color reading \\
\hline Chroma $\left(\mathrm{C}^{*}\right)$ & Rice bran & $9.17 \pm 0.83^{\mathrm{b}}$ \\
& Palm kernel cake & $8.23 \pm 0.63^{\mathrm{b}}$ \\
& Chlorella sp. & $7.33 \pm 1.24^{\mathrm{a}, \mathrm{b}}$ \\
& Yeast & $5.27 \pm 0.77^{\mathrm{a}}$ \\
Lightness $\left({ }^{*} \mathrm{~L}\right)$ & Rice bran & $69.06 \pm 2.65^{\mathrm{b}}$ \\
& Palm kernel cake & $62.84 \pm 2.64^{\mathrm{a}, \mathrm{b}}$ \\
& Chlorella sp. & $55.65 \pm 3.70^{\mathrm{a}}$ \\
& Yeast & $55.39 \pm 4.54^{\mathrm{a}}$ \\
$\operatorname{Hue}\left(\mathrm{H}^{0}{ }_{\mathrm{ab}}\right)$ & Rice bran & $113.25 \pm 1.27^{\mathrm{b}}$ \\
& Palm kernel cake & $111.32 \pm 0.93^{\mathrm{b}}$ \\
& Chlorella sp. & $110.80 \pm 1.03^{\mathrm{b}}$ \\
& Yeast & $105.46 \pm 1.07^{\mathrm{a}}$ \\
\hline
\end{tabular}

\section{Proximate of Angelfish}

Different enrichments significantly affected the proximate analysis of $P$. scalare. Based on the results, higher mean values of protein, lipid and moisture were recorded when the angelfish larvae were fed with rice bran, with the mean values being $\left(69.87 \pm 2.19^{\mathrm{b}}\right),\left(18.90 \pm 1.01^{\mathrm{b}}\right)$ and $\left(47.54 \pm 17.88^{\mathrm{a}}\right)$, respectively. Meanwhile, a higher mean value of ash was recorded in the angelfish larvae fed with yeast $(31.26 \pm$ $\left.3.68^{\mathrm{a}}\right)$. The enrichment used in this study had a significant impact on the mean value of the body composition $(P=0.01, P=0.03, P=0.00$, $P=0.03 ; P<0.05)$.

Table 4: The body composition of the angelfish larvae fed with different enrichments. The different small letters indicate significant differences between different treatments $(P<0.05)$ Chlorella $s p$

\begin{tabular}{lll}
\hline Body Composition & Enrichment & Mean \\
\hline Protein & Rice Bran & $69.87 \pm 2.19^{\mathrm{b}}$ \\
& PKC & $64.19 \pm 2.13^{\mathrm{a}, \mathrm{b}}$ \\
& Chlorella sp. & $61.29 \pm 5.57^{\mathrm{a}, \mathrm{b}}$ \\
& Yeast & $57.27 \pm 3.68^{\mathrm{a}}$ \\
Lipid & Rice Bran & $19.75 \pm 1.95^{\mathrm{b}}$ \\
& PKC & $14.86 \pm 0.81^{\mathrm{a}, \mathrm{b}}$ \\
& Chlorella sp. & $15.99 \pm 0.71^{\mathrm{a}, \mathrm{b}}$ \\
Yoisture & Yeast & $14.21 \pm 3.20^{\mathrm{a}}$ \\
& Rice Bran & $81.58 \pm 1.48^{\mathrm{b}}$ \\
& PKC & $73.09 \pm 2.18^{\mathrm{a}}$ \\
& Chlorella sp. & $71.55 \pm 0.80^{\mathrm{a}}$ \\
Ash & Yeast & $70.81 \pm 0.49^{\mathrm{a}}$ \\
& Rice Bran & $24.54 \pm 6.12^{\mathrm{a}}$ \\
& PKC & $22.84 \pm 5.13^{\mathrm{a}, \mathrm{b}}$ \\
& Chlorella sp. & $17.04 \pm 7.39^{\mathrm{a}}$ \\
& Yeast & $36.85 \pm 6.23^{\mathrm{b}}$ \\
\hline
\end{tabular}




\section{Proximate of Copepod}

The proximate analysis of copepod was carried out and copepod enriched with rice bran showed high levels of protein, lipid and moisture (69.87 $\left.\pm 2.19^{\mathrm{b}}\right),\left(21.09 \pm 1.99^{\mathrm{b}}\right)$ and $\left(84.18 \pm 0.99^{\mathrm{a}}\right)$ but low level of ash $\left(24.54 \pm 6.12^{\mathrm{a}, \mathrm{b}}\right)$, compared with the protein, lipid, moisture and ash levels in PKC, Chlorella sp. and yeast, with the values being $\left(66.19 \pm 2.16^{\mathrm{b}, \mathrm{c}}, 14.86 \pm 0.81^{\mathrm{a}}, 78.08 \pm\right.$ $2.82^{\mathrm{b}}$ and $\left.22.84 \pm 5.13^{\mathrm{a}, \mathrm{b}}\right),\left(60.80 \pm 3.73^{\mathrm{a}, \mathrm{b}}, 18.99\right.$ $\pm 0.71^{\mathrm{b}}, 82.72 \pm 3.02^{\mathrm{a}, \mathrm{b}}$ and $\left.1.57 \pm 0.92^{\mathrm{a}}\right)$ and $\left(57.99 \pm 2.45^{\mathrm{a}}, 13.21 \pm 1.55^{\mathrm{a}}, 78.68 \pm 0.34^{\mathrm{a}, \mathrm{b}}\right.$ and $5.95 \pm 1.53^{\mathrm{b}}$ ), respectively. The body composition of the copepods depends on type of enrichment provided $(P<0.05$; Table 5).

Table 5: The body composition of Apocyclop ramkhamhaengi enriched with different enrichments. The different small letters indicate significant differences between different treatments $(P<0.05)$

\begin{tabular}{lll}
\hline Body Composition & Enrichment & Mean \pm SD \\
\hline Protein & Rice bran & $69.58 \pm 3.48^{\mathrm{c}}$ \\
& PKC & $66.19 \pm 2.16^{\mathrm{b}, \mathrm{c}}$ \\
& Chlorella sp. & $60.80 \pm 3.73^{\mathrm{a}, \mathrm{b}}$ \\
& Yeast & $57.99 \pm 2.45^{\mathrm{a}}$ \\
\hline Lipid & Rice bran & $21.09 \pm 1.99^{\mathrm{b}}$ \\
& PKC & $14.86 \pm 0.81^{\mathrm{a}}$ \\
& Chlorella sp. & $18.99 \pm 0.71^{\mathrm{b}}$ \\
& Yeast & $13.21 \pm 1.55^{\mathrm{a}}$ \\
\hline Moisture & Rice bran & $84.18 \pm 0.99^{\mathrm{a}}$ \\
& PKC & $78.08 \pm 2.82^{\mathrm{b}}$ \\
& Chlorella sp. & $82.72 \pm 3.02^{\mathrm{a}, \mathrm{b}}$ \\
& Yeast & $78.68 \pm 0.34^{\mathrm{a}, \mathrm{b}}$ \\
\hline Ash & Rice bran & $4.15 \pm 2.49^{\mathrm{a}, \mathrm{b}}$ \\
& PKC & $3.04 \pm 0.97^{\mathrm{a}, \mathrm{b}}$ \\
& Chlorella sp. & $1.57 \pm 0.92^{\mathrm{a}}$ \\
& Yeast & $5.95 \pm 1.53^{\mathrm{b}}$ \\
\hline
\end{tabular}

\section{Discussion}

The development in enrichment protocols to promote further larvae growth, survival rate and colouration, leads to an increasing need to examine new potentials of live feed for the aquaculture industry. The nutritional requirements of copepods must also be thoroughly understood to support their growth so that they can be produced on a large scale. However, recent studies on this matter have produced a lack of result. Exploring potential new enrichment of live feed, such as using an organic base is necessary for the continued development of better enrichment options that can assist larval rearing in commercial realms. A possible new enrichment that could be applied for fish in larvae farming was the encouraging outcome of these findings.

The findings of this analysis showed that enrichment was necessary for the maintenance of angelfish larvae and had a significant impact on their development, survival and colouration. The specific growth rate, survival rate and colouration of the angelfish larvae clearly depended on the type of enrichment used for feeding. Based on the results (Table 1, Table 3 ), the best results for specific growth rate and colouration came from the use of rice bran, with the resulting values of $\left(8.39 \pm 0.33^{\mathrm{b}} \% ; 9.17 \pm\right.$ $\left.0.83^{\mathrm{b} * \mathrm{C}}, 69.06 \pm 2.65^{\mathrm{b}} * \mathrm{~L}, 113.25 \pm 1.27^{\mathrm{b}} \mathrm{H}^{0}{ }_{\mathrm{ab}}\right)$, 
respectively. According to Ryan (2011), rice bran has a high nutritious mixture that can increase the growth and survival rates of fish larvae, and this is supported by Chhay et al. (2010). Meanwhile, PKC enhanced the growth and survival rates (Zahari \& Alimon, 2005). According to Rao (2000), rice bran with 15 to $20 \%$ oil, can serve as a good source of energy and essential fatty acids (EFA). The survival of angelfish larvae depended on the enrichment type $(P=0.01 ; P$ $<0.05$ ). This experiment showed that (Table 2), the higher survival rate of angelfish larvae came from Chlorella sp. (72.33 $\left.\pm 2.52^{\mathrm{b}} \%\right)$ (Table 4 ) and the survival rate of angelfish larvae fed with rice bran, PKC and yeast were $(66.67 \pm$ $6.73 \%),(65.33 \pm 5.84 \%)$ and $(65.33 \pm 6.83 \%)$, respectively. According to some researches, angelfish fed with diet containing high levels of protein showed better growth and survival rates (Dars et al., 2010; Millikin et al., 1980). Furthermore, there were significant differences between the distribution for colour assessments and there were same across categories of treatments $(P=0.01, P=0.004, P=0.00 ; P<0.05)$. According to Kouba et al. (2013) the annexation of enrichment containing the carotenoid will affect the pigmentation of angelfish. An organic base can also enhance the colouration of the fish (Bunch, 1997).

Sadique et al. (2018) state that using rice bran as a diet replacement can increase the growth and the survival rates of fingerling fish. Rice bran contains gamma-oryzanol $(\gamma$ -oryzanol), which can provide bioactive lipidloaded nano-emulsions for food system, survival and growth (Zhong et al. 2018). The experiment by Maoka et al., 2008 shows that $\gamma$ - oryzanol provides higher level of colouration $\left(\mathrm{L}^{*}, \mathrm{a}^{*}\right.$ and $\left.b^{*}\right)$. Rice bran can enhance astaxanthin, lutein tunaxanthin, and that astaxanthin was converted to tunaxanthin by lutein (Yuangsoi et al., 2010). Astaxanthin is an excellent antioxidant in fish. It has, therefore, been strongly suggested that rice bran can preserve astaxanthin from radical decomposition in fish and also increase the accumulation of carotenoids in fish. Besides, rice bran is a nutritional and valuable byproduct, and is also a low-cost enrichment that can be used by small- and medium-scale farmers.
Proximate analyses were carried out to compare the body composition of angelfish $P$. scalare larvae after being fed with different enrichment of copepods (Table 4). A larvae feed with copepod enriched with rice bran showed the highest percentage of protein $(69.87$ $\left.\pm 2.19^{\mathrm{b}} \%\right)$ compared with other enrichments $(P=0.01 ; P<0.05)$. A post-larvae feed with copepod enriched with yeast showed the lowest percentage of protein at $57.27 \pm 2.19^{\mathrm{b}} \%$. Previous early studies on the rearing of fish larvae showed an optimum dietary protein level ranging from $24.2 \%$ to $79.5 \%$ (Watanabe et al., 1983). Protein contents of lower than $15 \%$ can cause mortality in fish larvae as protein is the first and foremost factor that has to be considered when formulating a fish feed. Based on the results (Table 5), yeast showed the lowest percentage of lipid (13.21 \pm

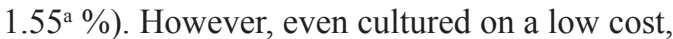
copepods fed with yeast produced relatively low population and reproductive performance development, mainly due to the low EFA content derived from copepods (Nanton et al., 2015). The moisture and ash contents were maximum in the body composition of angelfish larvae fed with copepod enriched rice bran $\left(84.18 \pm 0.99^{a}\right.$ $\%)$ and yeast $\left(5.95 \pm 1.53^{\mathrm{b}} \%\right)$, respectively. The minimum percentage of moisture was observed in angelfish larvae fed with copepod enriched with PKC $\left(78.08 \pm 2.82^{\mathrm{b}} \%\right)$. The lowest percentage of ash was found in fish fed with copepod enriched with Chlorella sp. (1.57 $\left.\pm 0.92^{\mathrm{a}} \%\right)$.

Because of its natural origin and poorly developed research among aquaculture researchers, rice bran and PKC have not been used widely in the industry. However, in terms of abundance and prevalence, the nutrient composition of these organic fertilisers has been found to influence the efficiency of planktons. (Gangadhara et al., 2017). However, rice bran and PKC are an excellent food and has many benefits compared with other live feed, such as microalgae. It is also present in abundant amounts, can be conveniently obtained at a low price, can be used immediately after drying, and can be kept for a longer period of time. Hence, it is also easy to dose and has little to do with 
the management of algae stock and cultivation (Zehra \& Altaff, 2002). In certain cases, dried algae are also excellent for live feed, but they are too expensive to use on a massive scale (DePauw et al., 1981). The use of microalgae in mass cultures is not cost-effective enough to satisfy aquaculture needs (Wang et al., 2017). There is a need for affordable feed to reduce the price of producing copepods (Drillet et al., 2011).

\section{Conclusion}

This study indicates that organic fertilisers, such as rice bran, can be used as an effective enrichment media for the growth, survival and colouration of fish larvae ( $P$. scalare) in the aquaculture industry. In terms of improving the nutritional value of live feeds, several enrichment procedures were still not enough for some fish larvae and could not exceed the nutritional contents of the copepod. Some fish larvae could not exceed the nutritional contents of the copepod. As copepods could not be enriched by traditional methods of enrichment, the organic base nutrition for copepods can be done to replace the nutritional composition. Copepods fed with rice bran have been shown to produce positive results on the growth rate, survival rate and colouration of fish larvae depending on the organic nutritional content fed to copepods. Further research is needed to understand the application of rice bran and PKC as enrichments of live feed that will result in high performance. It will also enable the future use of other enrichment formulae for live feed in ensuring the sustenance of fish larvae production in hatcheries.

\section{Acknowledgements}

The authors wish to thank the university for the opportunity to conduct this research, as well as the reviewers and editors for their constructive comments.

\section{References}

Association of Official Analytical Chemist. (1990). Official methods of analysis: change in official method of analysis made at the annual meeting. Supplement, 14.

Amar, E. C., Kiron, V., Satoh, S., \& Watanabe, T. (2001). Influence of various dietary synthetic carotenoids on bio-defence mechanisms in rainbow trout. Oncorhynchus mykiss (Walbaum). Aquaculture research, 32, 162173.

Berchielli-Morais, F. A., Fernandes, J. B. K., \& Sipaúba-Tavares, L. H. (2016). Diets supplemented with microalgal biomass: effects on growth, survival and colouration of ornamental fish Hyphessobrycon eques (Steindacher 1882). Aquaculture research, 47(10), 3061-3069.

Brown, R. J., Rundle, S. D., Hutchinson, T. H., Williams, T. D., \& Jones, M. B. (2003). A copepod life-cycle test and growth model for interpreting the effects of lindane. Aquatic toxicology, 63(1), 1-11

Bunch, G. W. (1997). U.S. Patent No. 5,618,574. Washington, DC: U.S. Patent and Trademark Office.

Bligh, E. G., \& Dyer, W. J. (1959). A rapid method of total lipid extraction and purification. Canadian journal of biochemistry and physiology, 37(8), 911917.

Busch, K. E. T., Peruzzi, S., Tonning, F., \& Falk-Petersen, I. B. (2011). Effect of prey type and size on the growth, survival and pigmentation of cod (Gadus morhua L.) larvae. Aquaculture Nutrition, 17(2), e595-e603.

Conceição, L. E., Yúfera, M., Makridis, P., Morais, S., \& Dinis, M. T. (2010). Live feeds for early stages of fish rearing. Aquaculture research, 41(5), 613-640.

Craig, S., Helfrich, L. A., Kuhn, D., \& Schwarz, M. H. (2017). Understanding fish nutrition, feeds, and feeding. Virginia State University. 
Das, P., Mandal, S. C., Bhagabati, S. K., Akhtar, M. S., \& Singh, S. K. (2012). Important live food organisms and their role in aquaculture. Frontiers in aquaculture, 5(4), 69-86.

Dhont, J., Dierckens, K., Støttrup, J., Van Stappen, G., Wille, M., \& Sorgeloos, P. (2013). Rotifers, artemia and copepods as live feeds for fish larvae in aquaculture. In Advances in aquaculture hatchery technology (pp. 157-202).

DePauw, R. A., Dunn, N. C., \& Lucas, J. R. (1981). U.S. Patent No. 4,244,380. Washington, DC: U.S. Patent and Trademark Office.

Dars, B. A., Narejo, N. T., Dayo, A., Lashari, P. K., Laghari, M. Y., \& Waryani, B. (2010). Effect of different protein on growth and survival of Catla catla (Hamilton) reared in glass aquaria. Sindh University Research Journal-SURJ (Science Series), 42(1).

Drillet, G., Frouël, S., Sichlau, M. H., Jepsen, P. M., Højgaard, J. K., Joarder, A. K., \& Hansen, B. W. (2011). Status and recommendations on marine copepod cultivation for use as live feed. Aquaculture, 315(3-4), 155-166.

Espitia-Manrique, C. H.; Fernandes, J. B. K.; Sakomura, N. K.; Arias-Vigoya, A. A;.Nascimento. T. M. T.; Silva, E. P. and Mansano, C. F. M. 2017. Description of growth and body composition of freshwater angelfish (Pterophyllum scalare) by Gompertz model. Revista Brasileira de Zootecnia, 46(8), 631-637.

Evjemo, J. O., Reitan, K. I., \& Olsen, Y. (2003). Copepods as live food organisms in the larval rearing of halibut larvae (Hippoglossus hippoglossus L.) with special emphasis on the nutritional value. Aquaculture, 227(1-4), 191-210.

Feltwell, J. (2016). Black and White in the Wild. RedDoor Publishing.

Gangadhar, B., Umalatha, H., Hegde, G., Vasundhara, R., \& Sridhar, N. (2017). Influence of commonly used manures on the growth and nutrient composition of periphyton. Insights in Aquaculture and Biotechnology, 1, 1-6.

Gouveia, L., and P. Rema. 2005. Effect of microalgal biomass concentration and temperature on ornamental goldfish (Carassius auratus) skin pigmentation. Aquaculture Nutrition, 11, 19-23.

Gul, K., Yousuf, B., Singh, A. K., Singh, P., \& Wani, A. A. (2015). Rice bran: Nutritional values and its emerging potential for development of functional food-A review. Bioactive Carbohydrates and Dietary Fibre, 6(1), 24-30.

Hamre, K., Yúfera, M., Rønnestad, I., Boglione, C., Conceição, L. E., \& Izquierdo, M (2013). Fish larval nutrition and feed formulation: knowledge gaps and bottlenecks for advances in larval rearing. Aquaculture, 5, S26-S58.

Jain, S. K., \& Singh, P. (2000). Economic analysis of industrial agroforestry: poplar (Populus deltoides) in Uttar Pradesh (India). Agroforestry systems, 49(3), 255273.

Koca, s. B., Diler, i., Dulluc, a., Yigit, n. O., \& Bayrak, h. (2009). Effect of different feed types on growth and feed conversation ratio of angel fish (Pterophyllum scalare Lictenstein, 1823). Journal of Applied Biological Sciences, (2), 7-11.

Koehl, M. A. R., \& Strickier, J. R. (1981). Copepod feeding currents: Food capture at low Reynolds number1. Limnology and Oceanography, 26(6), 1062-1073

Kouba, A., Sales, J., Sergejevová, M., Kozák, P., \& Masojídek, J. (2013). Colour intensity in angelfish (Pterophyllum scalare) as influenced by dietary microalgae addition. Journal of Applied Ichthyology, 29(1), 193199.

Koven, W., Kolkovski, S., Hadas, H., Gamsiz, A., Tandler, A., 2001. Advances in development of microdiets for gilthead seabream Sparus aurata: A review. Aquaculture, 194, $107-$ 121. 
Lim, L. C., Dhert, P., \& Sorgeloos, P. (2003). Recent developments in the application of live feeds in the freshwater ornamental fish culture. Aquaculture, 227(1-4), 319-331.

Marcus, N. H. (2005). Calanoid copepods, resting eggs, and aquaculture. Copepods in aquaculture, 3-9.

Maoka, T., Tanimoto, F., Sano, M., Tsurukawa, K., Tsuno, T., Tsujiwaki, S., ... \& Takii, K. (2008). Effects of dietary supplementation of ferulic acid and $\gamma$-oryzanol on integument color and suppression of oxidative stress in cultured red sea bream, Pagrus major. Journal of oleo science, 57(2), 133137

McGraw, K. J., Hudon, J., Hill, G. E., \& Parker, R. S. (2005). A simple and inexpensive chemical test for behavioral ecologists to determine the presence of carotenoid pigments in animal tissues. Behavioral Ecology and Sociobiology, 57(4), 391-397.

Millikin, M. R., Biddle, G. N., Siewicki, T. C., Fortner, A. R., \& Fair, P. H. (1980). Effects of various levels of dietary protein on survival, molting frequency and growth of juvenile blue crabs (Callinectes sapidus). Aquaculture, 19(2), 149-161.

Moren, M., Næss, T., \& Hamre, K. (2002). Conversion of $\beta$-carotene, canthaxanthin and astaxanthin to vitamin A in Atlantic halibut (Hippoglossus hippoglossus L.) juveniles. Fish Physiology and Biochemistry, 27(1-2), 71-80.

Nanton, M. R., Lee, S. J., Atif, S. M., Nuccio, S. P., Taylor, J. J., Bäumler, A. J., ... \& McSorley, S. J. (2015). Direct visualization of endogenous Salmonella-specific B cells reveals a marked delay in clonal expansion and germinal center development. European Journal of Immunology, 45(2), 428-441.

Ortega-Salas, A. A., Cortés, G., \& ReyesBustamante, H. (2009). Fecundity, growth, and survival of the angelfish Pterophyllum scalare (Perciformes: Cichlidae) under laboratory conditions. Revista de Biologia Tropical, 57(3), 741-747.
ONIANWAH, I. F. F. (2018). Microorganisms in sustainable aquaculture development. International Journal of Medical Science in Clinical Research and Review, 1(01).

Palace, V. P., \& Werner, J. (2006). Vitamins A and $\mathrm{E}$ in the maternal diet influence egg quality and early life stage development in fish: a review. Scientia Marina, 70(S2), 4157.

Pearson, W. R. (2000). Flexible sequence similarity searching with the FASTA3 program package. In Bioinformatics methods and protocols (pp. 185-219). Humana Press, Totowa, NJ.

Praveenkumar, R., Shameera, K., Mahalakshmi, G., Akbarsha, M. A., \& Thajuddin, N. (2012). Influence of nutrient deprivations on lipid accumulation in a dominant indigenous microalga Chlorella sp., BUM11008: evaluation for biodiesel production. Biomass and bioenergy, 37, 6066.

Rao, B. N. (2000). Nutritive value of rice bran. NFI BULLETIN, 21(4), 5-7.

Rasdi, N. W., \& Qin, J. G. (2016). Improvement of copepod nutritional quality as live food for aquaculture: A review. Aquaculture Research, 47(1), 1-20.

Ryan, E. P. (2011). Bioactive food components and health properties of rice bran. Journal of the American Veterinary Medical Association, 238(5), 593-600.

Sharma, V. K., Sahni, K., \& Wadhwani, A. R. (2013). Photodermatoses in pigmented skin. Photochemical \& Photobiological Sciences, 12(1), 65-77.

Santhanam, P. (2012). Evaluation of the marine copepod Oithona rigida Giesbrecht as live feed for larviculture of Asian seabass Lates calcarifer Bloch with special reference to nutritional value. Indian Journal of Fisheries, 59(2), 127-134. 
Sadique, K. J., Pandey, A., Khairnar, S. Woods, C. M. C., \& Valentino, F. (2003). Frozen O., \& Kumar, B. N. (2018). Effect of fermented water hyacinth leaf meal on plankton productivity and gut content analysis of common carp (Cyprinus carpio). International Journal of Current Microbiology and Applied Science, 7(9), 1947-1959

Trujillo, O., Vanezis, P., \& Cermignani, M. (1996). Photometric assessment of skin colour and lightness using a tristimulus colorimeter: reliability of inter and intrainvestigator observations in healthy adult volunteers. Forensic science international, 81(1), 1-10.

Uyeno, D., \& Nagasawa, K. (2012). Two new species of the copepod Hatschekia Poche, 1902 (Siphonostomatoida: Hatschekiidae) from angelfishes (Pisces: Perciformes:Pomacanthidae) collected during the KUMEJIMA 2009 Expedition. Zootaxa, 3367(1), 49-59.

Wang, S. K., Wang, X., Miao, J., \& Tian, Y. T. (2018). Tofu whey wastewater is a promising basal medium for microalgae culture. Bioresource technology, 253, 7984.

Watanabe, T., Kitajima, C., \& Fujita, S. (1983). Nutritional values of live organisms used mysids as an alternative to live Artemia in culturing seahorses Hippocampus abdominalis. Aquaculture Research, 34(9), 757-763.

Zaleha, K., \& Busra, I. (2012). Culture of harpacticoid copepods: understanding the reproduction and effect of environmental factors. Aquaculture, 343-360.

Zhong, J., Yang, R., Cao, X., Liu, X., \& Qin, X. (2018). Improved physicochemical properties of yogurt fortified with fish oil $/ \gamma$-oryzanol by nanoemulsion technology. Molecules, 23(1), 56

Zehra, A., \& Altaff, K. (2002). Redescription of Mesocyclops aspericornis (Daday, 1906) (Copepoda: Cyclopoida) from an Indian pond. Journal of Plankton Research, 24(5), 481-493.

Zahari, M. W., \& Alimon, A. R. (2005). Use of palm kernel cake and oil palm by-products in compound feed. Palm oil developments, 40, 5-8

Zeng, C., Shao, L., Ricketts, A., \& Moorhead, J. (2018). The importance of copepods as live feed for larval rearing of the green mandarin fish Synchiropus splendidus. Aquaculture, 491, 65-71.

in Japan for mass propagation of fish: a review. Aquaculture, 34(1-2), 115-143. 